\title{
Tumor Proliferation Gene Expression Signature
}

National Cancer Institute

\section{Source}

National Cancer Institute. Tumor Proliferation Gene Expression Signature. NCI

Thesaurus. Code C120018.

A gene expression profile that predicts survival in mantle cell lymphoma. The lowest expression levels of cyclin D1 were associated with increased survival. 